\title{
THE IMPLICATIONS OF TAX MANEUVER: PRODUCTION OF OIL AND PETROCHEMICALS ${ }^{1}$
}

\author{
A. Kaukin, A. Knobel, A. Firanchuk
}

A tax maneuver in the oil and oil refining industries contributed to some changes in the pattern of production of petrochemicals: the total volume of oil refining decreased, while the volume of production of motor gasoline increased somewhat. It is to be noted that the tax maneuver had an effect on the pattern of exports of petrochemicals, too: with duties increased on residual oil its exports fell dramatically, while with export duties reduced on commercial gasoline, directly distilled gasoline and light and medium distillates their exports increased. Reduction of export duties on diesel fuel brought about growth in its share in the total exports of petrochemicals.

\section{Production of Oil and Petrochemicals}

Late in 2014, amendments of the tax legislation in the oil and oil-refining sector were approved and they were called a "tax maneuver"

According to the parameters of the tax maneuver, the ratio of the Russian oil price in the export duty calculation formula should be gradually reduced to $0.42,0.36$ and 0.30 in 2015, 2016 and 2017, respectively. Simultaneously, it was expected to increase the severance tax base rate to $\mathrm{Rb} 766$ per ton, $\mathrm{Rb} 857$ per ton and Rb 919 per ton, respectively. In addition to the above, export duty rates on petrochemicals linked to the value of export duties on oil were adjusted further: as regards light petrochemicals they decreased, while as regards dark ones, they rose. Also, some reduction of excises on petrochemicals was provided for.

The purpose of the above changes was to promote efficiency of the Russian oil refining industry which during the past few years produced a negative added value in terms of global prices. The complete version of the tax maneuver ${ }^{3}$, which was not actually implemented and was only partially reflected in changes of the legislation suggested that by means of nulling of export duties on oil and petrochemicals with a simultaneous raising of the severance tax rate on oil the Russian vertically integrated companies (VIC) would have motivation to modernize oil refineries, increase oil refining depth and change the pattern of petrochemicals so that either the share of light fractions increases or inefficient loss-making industries are closed down'.

1 This paper was originally published in Monitoring of Russia's Economic Outlook No.18(36). 2 Federal Law No.366-FZ of 24 November 2014 "On Amendment of Part Two of the Tax Code of the Russian Federation and Individual Statutory Acts of the Russian Federation".

3 For more details on factors behind the tax maneuver, refer to: G.I. Idrisov and S.G. SinelnikovMurylev. Export Oil Duties: It is Impossible to Abolish, It is Impossible to Preserve // The Neft Rossii. Issue No.12, December 2011, pp. 72-77; G.I. Idrisov and S.G. Sinelnikov-Murylev. Modernization or Conservation: The Role of Export Duties on Oil and Petrochemicals // The Economic Policy. 2012. No.3, pp. 5-19.

4 On the Effect of the Tax Maneuver on Oil and Gas Transfers in the Eurasian Economic Union. See: A.Yu. Knobel. The Eurasian Economic Union: The prospects of Development and Possible Obstacles // Voprosy Ekonomiki. 2015. No.3, pp. 87-108. 
In 2016, a deviation from the tax maneuver's initial parameters which were approved in 2014 - took place: reduction of oil exports was frozen for a year ${ }^{1}$, while the severance tax rate smoothly increased. Apparently, such changes were related to the need to increase budget revenues after the crisis 2015 year.

In terms of the consequences of those changes for volumes of oil production and refining in 2015-2016 ${ }^{2}$, the effect is insignificant (Fig. 1).

Despite the crises phenomena in the Russian economy, the volume of oil production rose every year ${ }^{3}$ (including 2016 on the basis of the results of the three quarters), while the share of refined oil fell gradually from $57.7 \%$ in 2014 to $53.9 \%$ in the first three quarters of 2016.

It is to be noted that the observed dynamics of oil production and refining could be related among other things to changes in domestic demand on petrochemicals; such changes were caused by a general drop in demand in the economy during the crisis period.

Changes in the output pattern of Russian oil refining companies are most explicit (Fig. 2). The ratio of the volume of produced motor gasoline to that of primary oil refining at refineries increased from $14.1 \%$ in 2014 to $14.4 \%$ and $14.5 \%$ in 2015 and the first three quarters of 2016, respectively. It is to be noted that a similar indicator for residual oil changed more considerably: from $28.7 \%$ in 2014 to $26.2 \%$ and $20.1 \%$ in 2015 and the first three quarters of 2016, respectively. The share of the produced diesel fuel fell from $28.2 \%$ to $27.9 \%$ and $27.3 \%$, respectively.

So, it can be cautiously stated ${ }^{4}$ that even the incomplete version of the tax maneuver contributed to some changes in the pattern of production of

1 According to the draft of the 2017 Federal Budget, the formula of calculation of export duties next year will correspond to the values approved in 2014. .

2 Henceforward, the dynamics of indicators in 2016 is described by changes in the first three quarters of 2016 as compared to the first three quarters of 2015.

3 The consequences of the crisis for the domestic oil industry were insignificant as compared to processing sectors as the new level of prices on oil was acceptable for producers: first, a larger portion of the industry's costs was denominated in rubles and, second, a drop in oil prices affected largely the state's revenues and not the oil industry. For more information, see: G. Idrisov, A. Kaukin, O. Morgunova and M. Turuntseva. The Two Centers of the Russian Industry // The Online Monitoring of Russia's Economic Outlook: Trends and Challenges of the Socioeconomic Development. Issue No.11 (September 2015), pp. 19-22.

4 The period under review is affected by consequences of crisis phenomena in the Russian economy. 
petrochemicals: the total volume of oil refining fell primarily due to reduction of output volumes of dark petrochemicals, while the output volume of motor gasoline increased somewhat.

\section{Exports of Oil and Petrochemicals}

The analysis of dynamics of the Russian exports of oil and petrochemicals shows that starting from 2004 exports of crude oil from Russia were fairly stable (in physical terms); their fluctuations amounted to $219 \mathrm{~m}$ tons

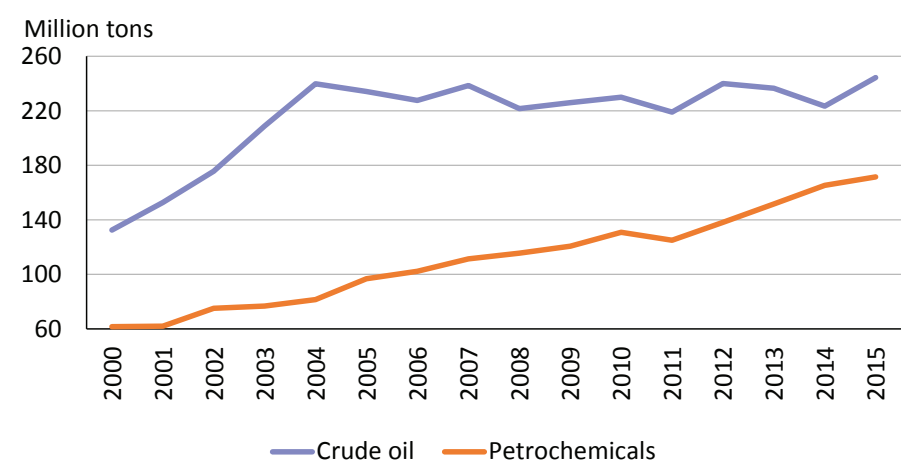

Source: RF Federal Customs Service.

Fig. 3. Dynamics of the Russian exports of crude oil and petrochemicals in 2000-2015 and $244 \mathrm{~m}$ tons in 2011 and 2015, respectively. At the same time, considerable growth in exports of petrochemicals continued (Group 2710 of the Harmonized System Codes) from $81 \mathrm{~m}$ tons in 2004 to $172 \mathrm{~m}$ tons in 2015 (Fig. 3).

Dynamics of exports of petrochemicals and crude oil are given in Table 1; the data were given for January-August of all the years for the sake of comparison with 2016. In the first eight months of 2016 physical volumes of exports of crude oil rose by $6 \%$ as compared to the same period of 2015, while the volumes of exports of petrochemicals in the first eight months of 2016 fell by $11 \%$, but still exceed the values of 2013. In 2013-2015, volumes of exports of residual fuel and diesel fuel were growing, but in 2016 they fell dramatically. It is to be noted that fairly sustained growth in physical volumes of exports was demonstrated by directly distilled gasoline, commercial gasoline, light distillates and lubricants.

Table 1

PHYSICAL VOLUMES OF EXPORTS OF CRUDE OIL AND PETROCHEMICALS, JANUARY-AUGUST OF THE RESPECTIVE YEAR

\begin{tabular}{|c|c|c|c|c|c|c|}
\hline \multirow[t]{2}{*}{ Name of the position } & \multicolumn{4}{|c|}{ Volumes of supplies, million tons } & \multicolumn{2}{|c|}{$\begin{array}{c}\text { Change in physical } \\
\text { volumes, } \%\end{array}$} \\
\hline & 2013 & 2014 & 2015 & 2016 & $2016 / 2013$ & $2016 / 2015$ \\
\hline Crude oil & 155.6 & 149.2 & 160.0 & 170.0 & +9 & +6 \\
\hline Petrochemicals: & 100.1 & 110.3 & 117.0 & 103.7 & +4 & -11 \\
\hline Residual oil & 55.3 & 57.3 & 61.0 & 48.4 & -12 & -21 \\
\hline Diesel fuel & 28.9 & 32.9 & 35.7 & 32.4 & +12 & -9 \\
\hline $\begin{array}{l}\text { Directly distilled } \\
\text { gasoline }\end{array}$ & 9.85 & 11.02 & 11.40 & 11.91 & +21 & +5 \\
\hline Commercial gasoline & 3.52 & 6.38 & 6.01 & 7.39 & +110 & +23 \\
\hline Other: & 2.6 & 2.7 & 2.9 & 3.5 & +37 & +19 \\
\hline $\begin{array}{l}\text { Light distillates; me- } \\
\text { dium distillates }\end{array}$ & 1.76 & 1.98 & 2.22 & 2.41 & +37 & +8 \\
\hline $\begin{array}{l}\text { Trimers and tetra- } \\
\text { mers of propylene }\end{array}$ & 0.02 & 0.02 & 0.02 & 0.01 & -28 & -32 \\
\hline Lubricants; other & 0.78 & 0.69 & 0.69 & 1.07 & +37 & +55 \\
\hline Waste oils & 0.0002 & 0.0002 & 0.0000 & 0.0002 & +5 & to 11-times \\
\hline Total & 255.79 & 259.54 & 277.01 & 273.65 & +7 & -1 \\
\hline
\end{tabular}

Source: the authors' calculations on the basis of the data of the RF Federal Customs Service.

Dynamics of the unit weight of different petrochemicals in the total exports of petrochemicals (to all the countries, except for the Eurasian Economic 


\section{CHANGES IN THE PATTERN OF EXPORTS OF PETROCHEMICALS TO ALL THE COUNTRIES, EXCEPT FOR MEMBER - STATES OF THE EURASIAN ECONOMIC UNION, JANUARY-AUGUST OF THE RESPECTIVE YEAR}

\begin{tabular}{|c|c|c|c|c|c|c|c|c|}
\hline \multirow[t]{2}{*}{ Name of the position } & \multicolumn{4}{|c|}{$\begin{array}{l}\text { Share of the com- } \\
\text { modity group in the } \\
\text { volume of exports of } \\
\text { petrochemicals, \% }\end{array}$} & \multicolumn{2}{|c|}{ Change in share, p.p.. } & \multicolumn{2}{|c|}{$\begin{array}{l}\text { Change in calcula- } \\
\text { tion ratio for the } \\
\text { export duty on pet- } \\
\text { rochemicals, p.p. of } \\
\text { the oil export duty }\end{array}$} \\
\hline & 2013 & 2014 & 2015 & 2016 & $2016 / 2013$ & $2016 / 2015$ & $2016 / 2013$ & $2016 / 2015$ \\
\hline Residual oil & 56.7 & 53.1 & 53.2 & 47.8 & -8.8 & -5.4 & +16 & +6 \\
\hline Diesel fuel & 29.2 & 30.0 & 30.8 & 31.5 & +2.2 & 0.7 & -26 & -8 \\
\hline Directly distilled gasoline & 10.2 & 10.2 & 9.8 & 11.7 & +1.6 & +1.9 & -19 & -14 \\
\hline Commercial gasoline & 1.9 & 4.7 & 4.0 & 6.0 & +4.1 & +2.0 & -29 & -17 \\
\hline $\begin{array}{l}\text { Light distillates; medi- } \\
\text { um distillates }\end{array}$ & 1.3 & 1.5 & 1.7 & 2.0 & +0.7 & +0.3 & -26 & -8 \\
\hline Lubricants; other & 0.7 & 0.6 & 0.5 & 1.0 & +0.3 & +0.4 & +16 & +6 \\
\hline
\end{tabular}

Source: the authors' calculations on the basis of the data of the RF Federal Customs Service.

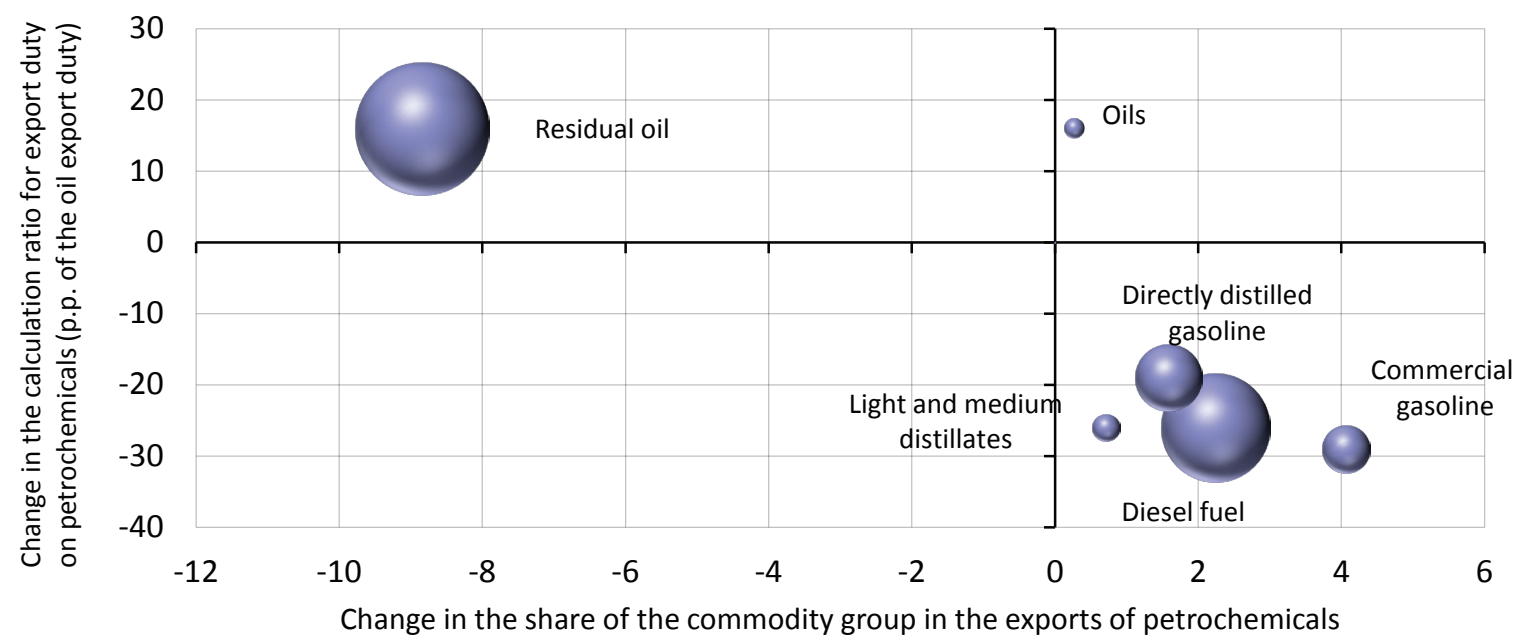

(in 2013-2016), p.p.

Note. The size of marker is proportional to the export volume.

Source: the authors' calculations on the basis of the data of the RF Federal Customs Service.

Fig. 4. Dynamics of shares of commodity groups in the exports of petrochemicals (to all the countries, except for the Eurasian Economic Union) and change in export duties for those groups

Union) correlates negatively with changes in export duties ${ }^{1}$ on those types of commodities (Table 2 and Fig. 4). With no export duties imposed on oil and petrochemicals for the countries of the Eurasian Economic Union, Russia explicitly subsidies the economies of those countries².

The export duty was increased as a whole by 0.16 of the oil export duty for residual oil, oils and waste oils (the share of the latter is negligible). Due to a 8.8 p.p. drop in the share of residual oil (from $56.7 \%$ in January-August 2013 to $47.8 \%$ in 2016), the shares of other petrochemicals increased. It is to

1 As percentage of the export duty on crude oil, the so-called calculation ratio for export duties on petrochemicals.

2 For more details about the effect of the tax maneuver on Russia's value of the oil and gas transfer, see: A.Yu.Knobel The Eurasian Economic Union: Prospects of Development and Possible Obstacles // Voprosy Ekonomiki. 2015. № 3. Pp. 87-108. 
be noted that the exports of commercial gasoline increased the most (both in relative and absolute terms); export duties on that gasoline were reduced by 0.29 of the oil export duty.

Also, there was growth in shares of other commodity groups for which the export duty was reduced (Table 2). So, it can be concluded that the tax maneuver had a direct effect on the export pattern of petrochemicals: all the large commodity groups (with a share of over $1 \%$ in the exports of petrochemicals) showed a negative effect of the calculation ratio for the export duty on petrochemicals (p.p. of the oil export duty) on changes in shares of commodity groups in the total exports of petrochemicals. 